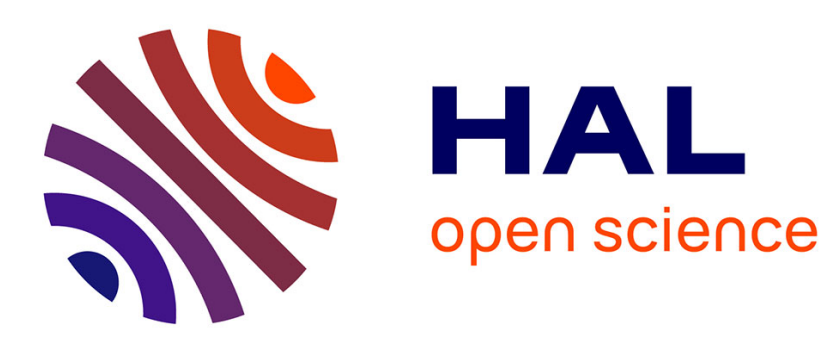

\title{
Relevant Capabilities for Information Management to Achieve Industrie 4.0 Maturity
}

Volker Stich, Sebastian Schmitz, Violett Zeller

\section{To cite this version:}

Volker Stich, Sebastian Schmitz, Violett Zeller. Relevant Capabilities for Information Management to Achieve Industrie 4.0 Maturity. 18th Working Conference on Virtual Enterprises (PROVE), Sep 2017, Vicenza, Italy. pp.28-38, 10.1007/978-3-319-65151-4_3 . hal-01674865

\section{HAL Id: hal-01674865 \\ https://hal.inria.fr/hal-01674865}

Submitted on 3 Jan 2018

HAL is a multi-disciplinary open access archive for the deposit and dissemination of scientific research documents, whether they are published or not. The documents may come from teaching and research institutions in France or abroad, or from public or private research centers.
L'archive ouverte pluridisciplinaire HAL, est destinée au dépôt et à la diffusion de documents scientifiques de niveau recherche, publiés ou non, émanant des établissements d'enseignement et de recherche français ou étrangers, des laboratoires publics ou privés.

\section{(c)(1)}

Distributed under a Creative Commons Attribution| 4.0 International License 


\title{
Relevant Capabilities for Information Management to Achieve Industrie 4.0 Maturity
}

\author{
Volker Stich, Sebastian Schmitz and Violett Zeller \\ ${ }^{1}$ FIR at RWTH Aachen, Institute for Industrial Management, Campus-Boulevard 55, \\ 52074 Aachen, Germany \\ $\{$ Volker.Stich, Sebastian.Schmitz, Violett.Zeller\}@,fir.rwth-aachen.de
}

\begin{abstract}
Industrie 4.0 is changing the industrial landscape in an unanticipated way. The vision for manufacturing industries is to transform to an agile company, in order to react on occurring events in real-time and make data based decisions. The realization requires also new capabilities for the information management. To achieve this goal agile companies require taking measured data, analyzing it, deriving knowledge out of this and support with the knowledge their employees. This is crucial for a successful Industrie 4.0 implementation, but many manufacturing companies struggling with these requirements. This paper identifies the required capabilities for the information management to achieve a successful Industrie 4.0 implementation.
\end{abstract}

Keywords: Industrie 4.0 · agile company · information management manufacturing companies

\section{Introduction}

The term "Industrie 4.0" - or labelled with different terms as "Industrial Internet of Things" in USA - describes the widespread integration of information and communication technology in industrial manufacturing [1]. Industrie 4.0 can be defined scientifically as real-time, multilateral communication and data transmission between cyber-physical devices with high data volumes rates [2]. The main benefit in realizing Industrie 4.0 concepts is the transformation of companies to an agile and learning company in order to be competitive in a growing dynamic business market. Many studies have shown that manufacturing companies are highly interested in capturing the named benefit within a targeted timeline of five years [3; 4]. However, the actual implementation speed is too slow to achieve this goal. Use cases are dominant, but an end-to-end implementation is necessary to realize the presented potentials. A systematic implementation in companies has not been conducted and companies need a precise development path for a holistic implementation of Industrie 4.0.

Due to the Industrie 4.0 definition, one action field is information management. An efficient information management is the key for successful companies to ensuring that available data and information can be used to make decisions. The relevant task in the information management and its influence on production processes are not transparent for manufacturing companies $[4,5]$. 


\section{Vision of Industrie 4.0 for Manufacturing Companies}

The overall objective for producing companies is continuous, long-term enhancement of liquidation and stakeholder value. Quality and time objectives replace traditional objectives like a substantial margin especially in high-wage countries [6]. Flexibility is the key for manufacturing companies to produce and deliver products in high quality and adapt to customer requirements fast. New market entrants, ever-shorter product lifecycles and customized solutions increase the required agility of companies. Industrie 4.0 enables flexibility and agility as two success factors for producing companies [7].

With a better availability of data and information, companies can learn how things are related to each other and can make faster decisions. A faster reaction to events achieve agility, as one key capability required by companies in Industrie 4.0 [2]. Derived from this vision, four corresponding Industrie 4.0 levels describe the business value of Industrie 4.0 for manufacturing companies. The Figure 1 shows Industrie 4.0 levels defined by the acatech - the national academy of science and engineering [2]. The definition of these levels represent following Industrie 4.0 maturity levels [2]: The starting point is the digital visibility of events in the company. This means that all processes and events leave a digital trace. In order to achieve this goal, all kinds of processes, such as management, business or supporting processes have to be captured digitally and be available in real-time. All data are processed and displayed in an appropriate level of detail for the given use-case. Having achieved visibility, decisions are information-based rather than assumption-based.

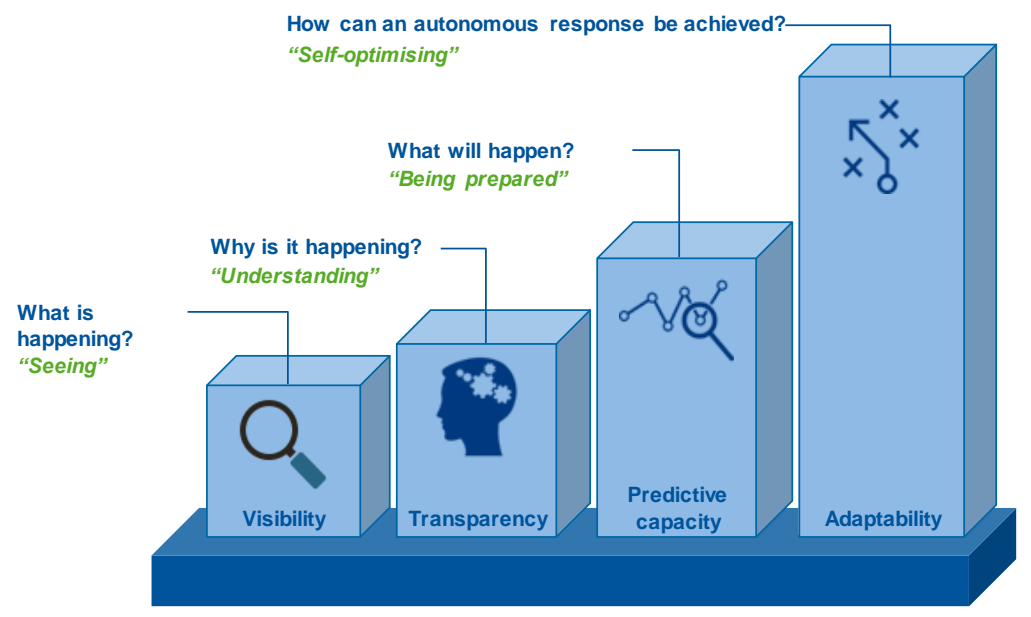

Fig. 1: Industrie 4.0 Maturity Levels [2]

Given the real-time availability of all relevant data, companies can reach the next maturity level of transparency resulting from understanding cause-and-effect relationships in the obtained data. Created process knowledge derived from context specific data combination and aggregation granted decision support. Big Data applications are used in environments where traditional methods of data analysis fail due to size and scope of obtained data. With the help of stochastic methods, these 
applications reveal unknown cause-and-effect relationships in producing companies. Big data applications fed systems, like enterprise resource planning (ERP) and manufacturing execution systems (MES), with the aggregated data. The configuration of these applications allows that data are transmitted to the right software automatically.

The next target level predictability bases on identified cause-and-effect relationships. The conducted measures grant a comprehensive and reliable input in order to make better forecasts and predictions. Probabilistic methods forecast events in the future and developed strategies face them in advance. Hence, best possible reactions can be determined more reliably and initiated faster. With these new capabilities in predicting the company's market environment, the number of unexpected events decreases. Thus, production planning achieves a new level of reliability. The quality of the prognoses is highly dependent to the preliminary work done in the described former stages. Information quality is resulting from a comprehensive digital signature and defined cause-and-effect relationships. Quantifying information quality is crucial in order to make valid prognoses yet remains a challenge. Both practical and expert knowledge are key factors in order to generate sound prognoses.

Companies can accomplish the final level self-optimization by continuously adapting insights given by transparency and visibility. In manufacturing, selfoptimization controls automatically controlling the manufacturing process. All factors essential to the company's success are included in such a system (e.g. production planning, production control). In order to decide which steps to automate, companies have to determine and evaluate costs and benefits for all manufacturing steps. Repeating manufacturing steps should always be considered when examining the capability to run autonomously. When communicating with suppliers and customers, approval and confirmation notifications have to be supervised critically. Companies reach the target of self-optimization when they able to use the digital signature in a way that the system is able to make decisions quickly and put their measures into practice fast with the best possible outcome for the company.

\section{Industrie 4.0 Requirements to the Information Management}

All four Industrie 4.0 levels have in common, that relevant information in right time, place and quality are required to enable these databased decisions and achieve business value. Providing time-critical information in the right quality to the right decision maker is the main task of information management and enables companies to achieve targets like flexibility, quality and time objectives. Therefore, this business function handles processes and information systems in order to provide, process, save, generate and transfer data and information to all business processes. This includes data processing to generate knowledge out of data [8]. Information systems are sociotechnical systems in which information is provided based on economic criteria by both people and information and communication technology [9].

In order to provide decision-relevant information, access and confidentiality of all required data has to be ensured and a detailed digital picture of the production system 
has to be enabled. Only providing is not enough. Information have to be filtered, clustered and showing relationships, so that data analysis is a required capability for manufacturing companies. Data processing and interpretation transform raw data into valuable information and knowledge [10]. Data preparation and visualizations reduces for users the complexity of relations. Furthermore, the communication between users and systems has to be bidirectional to enable the user to feed information back.

Providing data and information for decisions, companies' data have to be available throughout different IT systems like Enterprise resource planning (ERP). To do this, it is necessary to create an information system architecture for agile companies with a central platform. This requires horizontal and vertical integration, standardized exchange formats and interfaces as well as appropriate data quality.

\section{Methodical Approach of this Paper}

The overall target of the research activity is to identify relevant Industrie 4.0 capabilities of the information management and integrate these capabilities in an Industrie 4.0 maturity model - e.g the acatech Industrie 4.0 maturity index. To achieve that overall target the research activity is split into three models, see figure 2 . Content of this paper will be the development of the first model. This model derives the required capabilities from literature analysis. The literature analysis bases on relevant Industrie 4.0 studies and fundamental work of information management. The identified capabilities are discussed and validated with expert, who are involved in the acatech project "Industrie 4.0 maturity index" [2]
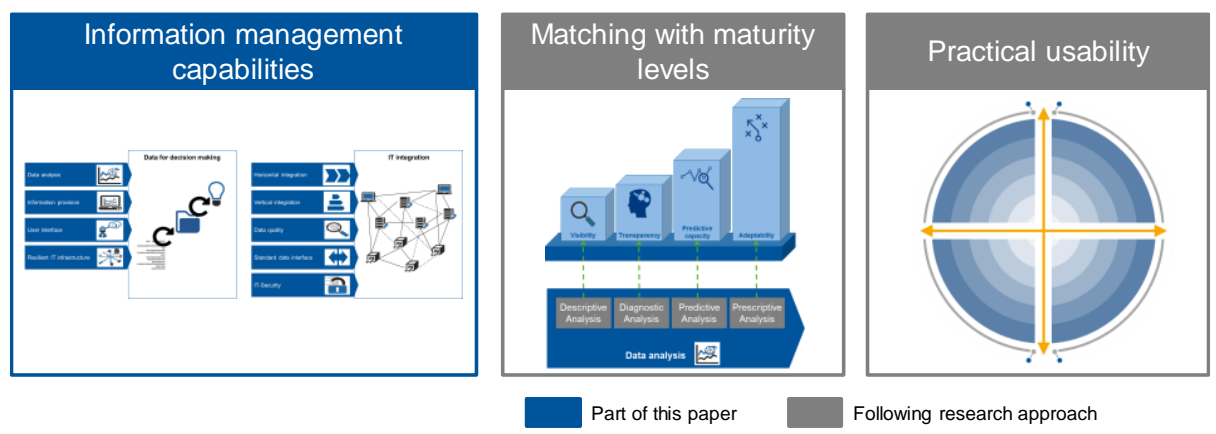

Following research approach

Fig. 2: Methodical approach of this paper

\section{Industrie 4.0 Capabilities to the Information Management}

Derived from the requirement, this chapter describes the Industrie 4.0 capabilities to the information management. For a successful Industrie 4.0 implementation, two principles are relevant. First, available data should be prepared and processed in a manner that supports decision-making. In order for the data to be usable, the organization must meet technical requirements for real-time access and possess an infrastructure that enables the necessary data processing and seamless information 
delivery. Second, manufacturing companies require an IT integration in order to enhance data use and increase agility [2]. To realize both principles, producing companies have to possess a level of capabilities. It is the task for the information management to ensure that capabilities and develop a roadmap to realize these capabilities. Figure 3 shows an overview of the required capabilities. An explanation of these capabilities are followed in detail.
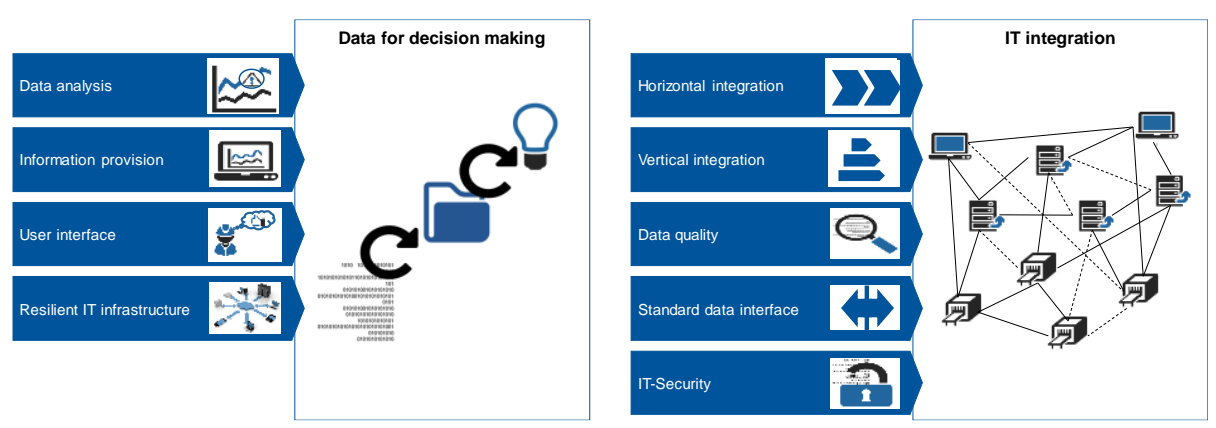

Fig. 3: Required Industrie 4.0 capabilities for a successful implementation

\section{Data analysis}

Data analysis defines the transformation process from data into information to use the information for valuable decisions [11]. The degree of digitization and interdependence of production plants is continuously increasing. This results directly in an increasing amount of data. Literature describes data analysis along four levels basing on each other: The descriptive analysis describes the evolvement from data to information by putting data into context. In the next step, cause-effect relationships are revealed by conducting correlation analyses (diagnostic analyses). Within the predictive data analysis, events in the future are forecasted by methods of simulation or regression. Last, prescriptive data analysis provides recommendations for action by using optimization algorithms and simulation approaches [12]. Within a digital environment, commonly referred to as "Industrie 4.0", a large and poly-structured amount of data is available and exceed traditional analysis methods ("Big Data") [13]. New technology enable an efficient processing of these data. Use-cases for data analysis in an "Industrie 4.0"-environment are forecasting machine failures and an optimized production planning process.

\section{Information provision}

Information provision includes the suitable provision of information [14]. Due to increasing amount of information, companies focusing on an efficient information provision [15]. Delivering contextualized information to employees allows that they use the results of the data analysis to support their decision-makings. Companies have to make sure, that the provided information are the right information in that situation. 
Methods like information modelling or information logistic concepts identify the right information [16].

Instead of searching for the information across several different IT systems and processes, sorting or interpreting it themselves, the IT system delivered the right information in accordance of the specific context of the actual task and the right content. The term system-of-engagement describes an efficient information provision. Systems of engagement focus on the employees instead of daily processes, like systems of enrichment. These system of engagement works similar to apps and collect all required information from available IT-Systems and show these in the right relation to the employees task [17].

Furthermore, companies have to ensure, that employees use the provided information and information system for their tasks and decisions. Not used information or systems leads to redundant data and missing feedback to former processes [18].

\section{User interface}

User interfaces describe the interface and interaction modus between IT systems and users [19]. IT systems can deliver information in form of tables, animations, Augmented Reality or voice. The better the information are displayed and corresponding to the actual process, companies reach potentials like increasing productivity or quality. Easily understandable visualisation (e.g. 3D-animations) reduces the decision complexity. Its content and presentation should be adapted to the task being performed and the employee's skill level. The used technology must be mobile, highly versatile and easily usable [20]. Users need intuitive possibilities to react on events and communicate with the IT systems. Depending on the actual task though, gesture or voice control are used [21].

\section{Resilient IT infrastructure}

Resilience defines how an IT system reacts under changes circumstances. Resilient IT systems are stable within foreseeable circumstances [22]. Data analysis and delivery require a resilient IT infrastructure that fulfils the relevant technical data capture, transfer, storage and processing requirements and guarantees the IT system's functionality. A common problem for manufacturing companies is the actual IT infrastructure, which is not designed for the big amount of data [23].

Backups or specialised software prevent threats to people and material assets and guarantee the system's long-term usability. Situation-based data storage ensures that applications can access the data within an appropriate timeframe. In-memory databases allow frequent accessing of the data, so that it can be used to provide rapid and stable decision-making support [24].

\section{Horizontal IT system integration}

The horizontal integration describes the integration of different process steps within a company. The integration contains operational, executional and administrational processes and IT systems. The horizontal integration abolish different version status 
over the value stream and enable a single source of truth [25]. A complete horizontal integration along the value stream and without media disruption enables companies to link the order information to product, work and process instructions $[26 ; 2]$. Companies can react flexible and data based due to an interconnection between engineering, planning and production data [27]. This interconnection include also an information feedback, e.g. the feedback of production parameter back to the production planning to adapt the planned production time. To implement a horizontal integration of the IT-systems local data storages have to opened and interfaces between IT-systems be connected. Common data storage is the basis for a companywide single source of truth. All users access the same set of information [2].

\section{Vertical IT-system integration}

A big amount of data is available throughout the value chain. To analyse these data and identify interdependencies between them, a vertical integration of IT systems is required. The vertical integration is one of the Industrie 4.0 key aspects [25]. IT systems and the machines on the field level exchange information continuously between them. It is necessary to create an information system architecture for agile companies with a central platform that connects existing IT systems to each other and provides contextualized information. The vertical IT integration focus on the integration of IT systems on different levels and the dissolution of the automation pyramid $[25 ; 26 ; 28]$. This means the dissolution of the IT systems structures and hierarchies.

\section{Standardize data interfaces}

Data interfaces describe the transition between two IT systems. Standardized data interfaces is the required communication basis in Industrie 4.0 [29-31]. A continuous information flow between the IT systems and the access for all users on the same set of information requires standardized data interfaces. Data interfaces facilitate the exchange of data and information from individual IT systems. Nowadays many interfaces are proprietary, which means that the interface works only in that individual use case [31]. To react agilely on changing IT-systems and information flows a flexible IT-landscape is required. Neutral or standard interfaces and data exchange formats across all the relevant systems are necessary for this flexible IT-landscape [17].

\section{Data quality}

Data quality means the degree of data usability for the individual purpose [32]. IT systems integration relies on sufficiently high data quality. Poor data quality in the IT systems results in incorrect aggregated data and inaccurate feedback, ultimately undermining confidence in both the IT systems and their contents [17]. This makes it impossible to achieve the goal of databased decision-making. Data governance policies provide organisations with guidance for the processing, storage, management and presentation of high-quality data within the company. Even a perfect data quality 
is impossible to reach, goal within the Industrie 4.0 vision is a "fit for use" [33]. Technical capabilities for improving data quality include automated data cleansing (identification, standardisation, duplicate removal, consolidation and enhancement of data) and master data management systems.

\section{Upgrade IT security}

The increasing integration of information systems as well as human factors and other contributors bear the risk of criminal attacks. The potential damage that these attacks can cause increases in proportion to the degree of integration. IT security encompasses different strategies for identifying and implementing security measures. Compliance with standards such as IEC 62443 can help to contain the risks. Such standards include proactive measures to maintain IT security and adapt it in response to changing circumstances [34].

\section{Conclusion and Outlook}

This paper describes possible capabilities for the information management in order to achieve the four maturity levels of Industrie 4.0 successfully. Companies have to master these capabilities to reach the overall goals of Industrie 4.0, like flexibility, quality and time objectives. All capabilities base on a literature research analysis. This paper defines the capabilities and presents the requirement for an Industrie 4.0 implementation.

The following research activities match these capabilities to the described Industrie 4.0 maturity levels. The maturity levels will be described by the configuration of each capability.

Figure 4 shows exemplarily the matching for the capability of data analysis. Literature separates data analysis into descriptive, diagnostic, predictive and prescriptive analysis. Target of the first maturity level is that data are processed and displayed in an appropriate level of detail for the given use-case. To reach this goal, data have to transfer to information by putting data into context. These requirements are given by descriptive analysis. The maturity level "transparency" is described by cause-and-effect relationships in the obtained data. Diagnostic analysis include correlations and identifies these cause-and-effect relationships. Predictive data analysis forecasts events in the future by methods of simulation or regression. This forecast is the central issue in the third maturity level predictability. Prescriptive data analysis provides recommendations for action and optimization algorithms. The fourth maturity level adaptability requires recommendations for action and optimization algorithms to react autonomously. 


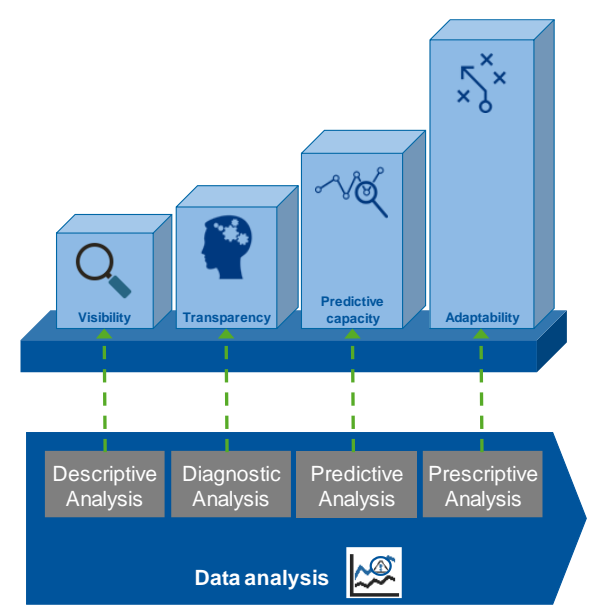

Fig. 4: Example for Matching of Capabilities to Maturity Levels

Following research activities will split and match all identified to the maturity levels. The allocation is used for a maturity model that assess the maturity degree of the information management. Furthermore, the validation of the presented approach will include interviews and assessments in producing companies in order to prove that the identified information management capabilities support the achievement of each Industrie 4.0 level.

\section{References}

1. Gudergan, Gerhard; Stich, Volker; Schmitz, Sebastian; Buschmeyer, Achim (2016): The Global Evolution of The Industrial Internet of Things. A Cross Country Comparison Based on an International Study on Industrie 4.0 for Asset Efficiency Management. In: Dimiter Dimitrov und Tiaan Oosthuizen (Hg.): Proceedings COMA'16, International Conference on Competitive Manufacturing. COMA'16. Stellenbosch, South Africa, 29. Januar 2016. Stellenbosch, South Africa: Department of Indutrial Engineering Stellenbosch University, S. 489-494.

2. Schuh, Günther; Anderl, Reiner; Gausemeier, Jürgen; ten Hompel, Michael; Wahlster, Wolfgang (2017): Industrie 4.0 Maturity Index. Managing the digital transformation. Hg. v. acatech. acatech. Munich.

3. Infosys (2015): Industry 4.0. The state of the nations. 1. Aufl. Hg. v. Infosys Ltd. Bangalore, Indien.

4. McKinsey (2015): Industry 4.0. How to navigate digitalization of the manufacturing sector. Unter Mitarbeit von Dominik Wee, Richard Kelly, Jamie Cattel und Matthias Breunig. Hg. v. McKinsey.

5. Zühlke, Detlef (2013): Die Cloud ist Voraussetzung für Industrie 4.0. Präsentation. VDI. VDI-Pressegespräch anlässlich des Kongresses „AUTOMATION 2013“. Baden-Baden, 6/25/2013. 
6. Schuh, Günther; Kampker, Achim; Stich, Volker; Kuhlmann, Kristian (2011): Prozessmanagement. In: Günther Schuh und Achim Kampker (Hg.): Strategie und Management produziernder Unternehmen. Handbuch Produktion und Management 1. Berlin, Heidelberg: Springer-Verlag Berlin Heidelberg (VDIBuch), S. 327-382.

7. Bauernhansl, Thomas; Krüger, Jörg; Reinhart, Gunther; Schuh, Günther: WGPStandpunkt Industrie 4.0. Hg. v. Wissenschaftliche Gesellschaft für Produktionstechnik Wgp e. V.

8. Mangiapane, Markus; Büchler, Roman P. (2015): Modernes IT-Management. Methodische Kombination von IT-Strategie und IT-Reifegradmodell. Wiesbaden: Springer Vieweg.

9. Krcmar, Helmut (2015): Einführung in das Informationsmanagement. 2., überarb. Aufl. 2015. Berlin, Heidelberg: Springer Gabler (Springer-Lehrbuch).

10. Geisberger, Eva; Broy, Manfred (2012): Integrierte Forschungsagenda CyberPhysical Systems. acatech Studie. Hg. v. Eva Geisberger und Manfred Broy. München, Garching, Berlin (acatech - Deutsche Akademtie der Technikwissenschaften).

11. Chen, Hsinchun; Chiang, Roger; Storey, Veda (2012): Business Intelligence and analytics. From Big Data to Big Impact. In: MIS Quarterly 36 (4), S. 1165-1188.

12. Shi-Nash, Amy; Hardoon, David (2017): Data Analytics and Predictive Analytics in the era of Big Data. In: Hwaiyu Geng (Hg.): The internet of things et data analytics handbook. Hoboken, New Jersey: John Wiley et Sons, S. 329-345.

13. Krumpe, Jens; Knoth, Adrian; Golla, Burkhard (2013): XaaS und Big-DataTechnologien. cloudoptimiertes Datenmanagement für Open-Government-Data. In: Josef Strobl, Thomas Blaschke, Gerald Griesebner und Bernhard Zagel (Hg.): Angewandte Geoinformatik 2013. Beiträge zum 25. AGIT-Symposium Salzburg. Berlin, Offenbach: Wichmann, S. 566-575.

14. Hermann, Mario; Pentek, Tobias; Otto, Boris (2016): Design Principles for Industrie 4.0 Scenarios. In: Tung X. Bui und Ralph H. Sprague (Hg.): Proceedings of the 49th Annual Hawaii International Conference on System Sciences. 49th Annual Hawaii International Conference on System Sciences. Kauai, Hawaii, 5-8 January 2016. Hawaii International Conference on System Sciences; Annual Hawaii International Conference on System Sciences; HICSS. Piscataway, NJ: IEEE, S. 3928-3937.

15. Fiebig, S.; Lehmann, M.; Wonneberger, K-U.; Münnich, M. (2014): Informationen auf dem Shopfloor. In: Bernd Rudow und Hans-Christian Heidecke (Hg.): Betriebliche Informationssysteme in der Automobilproduktion. Soziotechnisches System - Nutzerpersönlichkeit - Nutzungserleben - Rollout und Betrieb - Fabriksteuerung - Informationen auf Shopfloor - IT-Nutzen. München: Oldenburg Wissenschaftsverlag GmbH, S. 231-259.

16. Krcmar, Helmut (2015): Informationsmanagement. 6., überarb. Aufl. Berlin: Gabler (SpringerLink : Bücher).

17. Schuh, G.; Potente, T.; Thomas, C.; Hauptvogel, A. (2014): Steigerung der Kollaborationsproduktivität durch cyber-physische Systeme. In: Thomas Bauernhansl, Michael ten Hompel und Birgit Vogel-Heuser (Hg.): Industrie 4.0 in Produktion, Automatisierung und Logistik. Wiesbaden: Springer Fachmedien Wiesbaden, S. 277-296. 
18. Aier, Stephan; Schönherr, Martin (2007): Flexibilisierung von Organisations- und IT-Architekturen durch EAI. Technische Universität Berlin, Berlin. Competence Center EAI.

19. Calvary, Gaëlle; Coutaz, Joëlle; Thevenin, David; Limbourg, Quentin; Bouillon, Laurent; Vanderdonckt, Jean (2003): A Unifying Reference Framework for multitarget user interfaces. In: Interacting with Computers 15 (3), S. 289-308. DOI: 10.1016/S0953-5438(03)00010-9.

20. Fallenbeck, Nils; Eckert, Claudia (2014): IT-Sicherheit und Cloud Computing. In: Thomas Bauernhansl, Michael ten Hompel und Birgit Vogel-Heuser (Hg.): Industrie 4.0 in Produktion, Automatisierung und Logistik. Wiesbaden: Springer Fachmedien Wiesbaden, S. 397-431.

21. Vogel-Heuser, Birgit (2014): Herausforderungen und Anforderungen aus Sicht der IT und der Automatisierungstechnik. In: Thomas Bauernhansl, Michael ten Hompel und Birgit Vogel-Heuser (Hg.): Industrie 4.0 in Produktion, Automatisierung und Logistik. Wiesbaden: Springer Fachmedien Wiesbaden, S. 37-48.

22. Laprie, Jean-Claude (Hg.) (2008): From dependability to resilience. 38th IEEE/IFIP Int. Conf. On Dependable Systems and Networks. Anchorage.

23. Bartel, J.; Pfitzinger, B.; et al. (2012): Big Data im Praxiseinsatz. Szenarien, Beispiele, Effekte. Hg. v. BITKOM e.V. Berlin.

24. Porter, Michael E.; Heppelmann, James (2015): How Smart, Connected Products Are Transforming Companies. In: Harvard Business Review 93 (10), S. 97-114.

25. Kaufmann, Thomas; Forstner, Lisa (2014): Die horinzontale Integration der Wertschöpfungskette in der Halbleiterindustrie. Chancen und Herausforderungen. In: Thomas Bauernhansl, Michael ten Hompel und Birgit Vogel-Heuser (Hg.): Industrie 4.0 in Produktion, Automatisierung und Logistik. Wiesbaden: Springer Fachmedien Wiesbaden, S. 359-367.

26. Schlick, Jochen; Stephan, peter; Loskyll, Matthias; Lappe, Dennis (2014): Industrie in der praktischen Anwendung. In: Thomas Bauernhansl, Michael ten Hompel und Birgit Vogel-Heuser (Hg.): Industrie 4.0 in Produktion, Automatisierung und Logistik. Wiesbaden: Springer Fachmedien Wiesbaden, S. 57-82.

27. Bloching, Björn; Leutiger, Philipp; Oltmanns, Torsten; Rossbach, Carsten; Schlick, Thomas; Rename, Gerrit et al. (2015): Die digitale Transformation der Industrie. Hg. v. Roland Berger. München.

28. Mül-ler, Rainer; Vette, Matthias; Hörauf, Leenhard; Speicher, Christoph; Jatti, Kruttika (2015): Concept and implementation of an agent-based control architecture for a cyber-physical assembly system. In: Peter Platter, Guo Meixing und Sathans Suhag (Hg.): 3rd International Conference on Control, Mechatronics and Automation. MATEC Web of Conferences. MATEC Web of Conferences. Barcelona, Spanien, 21 - 22 December. Red Hook, NY: Curran Associates, S. 167-170.

29. Hoppe, Stefan (2014): Standardisierte horizontale und vertikale Kommunikation: Status und Ausblick. In: Thomas Bauernhansl, Michael ten Hompel und Birgit Vogel-Heuser (Hg.): Industrie 4.0 in Produktion, Automatisierung und Logistik. Wiesbaden: Springer Fachmedien Wiesbaden, S. 325-341. 
30. European Commission, Enterprise \& Industry Directorate General (2005): ebusiness w@tch. e-Business Interoperability and Standards. A Cross-Sector Perspective and Outlook. e-business watch. Brüssel.

31. Sindermann, Sebastian (2014): Schnittstellen und Datenaustauschformate. In: Martin Eigner, Daniil Roubanov und Radoslav Zafirov (Hg.): Modellbasierte virtuelle produktentwicklung. Berlin, Germany: Springer Vieweg, S. 327-347.

32. Heinrich, Lutz J.; Riedl, René; Stelzer, Dirk (2014): Informationsmanagement. Grundlagen, Aufgaben, Methoden. 11., vollst. überarb. Aufl. 2014. München: OLDENBOURG WISSENSCHAFTSVERLAG.

33. Strong, Diane M.; Lee, Yang W.; Wang, Richard Y. (1997): Data quality in context. In: Commun. ACM 40 (5), S. 103-110. DOI: 10.1145/253769.253804.

34. IEC 62443: Network and system security. 